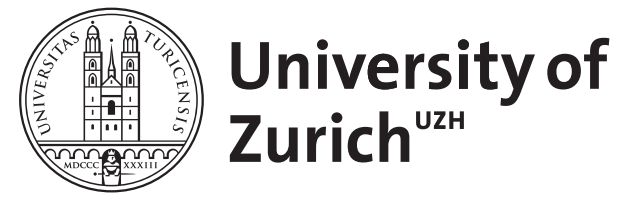

Dependent-Head synthesis in Nivkh - with an outlook on polysynthesis in the Far Northeast

Mattissen, Johanna

DOI: https://doi.org/10.1524/stuf.1999.52.34.298

Posted at the Zurich Open Repository and Archive, University of Zurich ZORA URL: https://doi.org/10.5167/uzh-154073

Journal Article

Published Version

Originally published at:

Mattissen, Johanna (1999). Dependent-Head synthesis in Nivkh - with an outlook on polysynthesis in the Far Northeast. STUF - Language Typology and Universals, 52(3-4):298-314.

DOI: https://doi.org/10.1524/stuf.1999.52.34.298 
Johanna MatTissen (Zürich)

\section{Dependent-Head synthesis in Nivkh - with an outlook on polysynthesis in the Far Northeast}

\section{Preliminary remarks}

Morphological synthesis phenomena have been described within the frameworks of polysynthesis, noun incorporation, or verb root serialization (Mithun 1988, ForTeSCue 1994, Baker 1996, Drossard 1997; Mithun 1984, Baker 1988, Rosen 1989, Gerdts 1996; Bisang 1995). While noun incorporation and verb root serialization focus on single domains of syntax, polysynthesis comprises a range of heterogeneous phenomena. In this paper a structural principle will be presented which organizes syntax in a homogeneous way through systematic synthesis of head and dependent. This structural principle will be referred to as dependent-head synthesis, with the concepts of head and dependent used here in the sense of NicHOLs (1986). A language which is consistently organized in this way is Nivkh (Gilyak).

\section{Basic typological characteristics of Nivkh}

Nivkh is an endangered language isolate (usually counted among the Paleosiberian language group) spoken on the lower reaches of the Amur river and on Sakhalin Island in Eastern Siberia in several dialects.

The predicate in Nivkh is clause-final. Syntactic relations are signalled by word order (central participants), case suffixes (peripheral participants), postpositions (local relations), and, most importantly, dependent-head synthesis: the primary object (in the sense of DRYER 1986) synthesizes with its governing verb. Agent or subject agreement is only found on some non-matrix predicate forms. Clausal nexion operates on a converbal basis.

Nivkh distinguishes number and has numeral classification. There is neither a gender nor an article system. Tense/aspect/mood categories are not fully grammaticalized. Grammatical categories are encoded through inflection of the agglutinative type (number, case and focus; causative and temporal, aspectoid and modal categories) and through auxiliaries (negation, phases of states of affairs, modalities).

\section{Nivkh morphophonemics}

For the recognition of dependent-head synthesis in Nivkh, morphophonemics play the decisive role. At the boundaries of adjacent lexical and/or grammatical morphemes initial and final consonant sounds are subject to morphophonemic alternations reminiscent of mutation in Celtic (cf. BALL/MülLER 1992). As the basis for the description of these alter- 
nations we take that form of a morpheme which represents the lexeme in a construction containing the morpheme in question alone, e.g. $t \partial f^{\prime}$ 'a/the house (NOM)'. In this case its initial sound is in absolute initial position and its final sound in absolute final position. This form serves as the citation form of a nominal lexeme (see SAVEL'EVA/TAKSAMI 1970). The citation form of a verbal lexeme, whose root cannot stand as a free form without at least one suffix, contains the suffix $-d q-t$ (Amur dialect), $-d \sim-n t$ (Sakhalin dialects) 'IND/NML' as its only suffix. This suffix assimilates with respect to voice to a root-final consonant (in case there is one) without inducing any sound changes, e.g. ev-gुl 'take s.th.' vs. esp-t 'stab s.o.'.

Due to the different types of morphophonemic alternations presented in (i) to (iii) below, lexemes and suffixes have from one to six allomorphs:

(i) Some morpheme-final fricatives manifest final devoicing in absolute final position (for examples see JAKOBSON 1971: 83).

(1) təf 'house' : təv-řə 'entrance door', təv-lotţ 'build a house'l

(ii) A morpheme-initial fricative or plosive alternates depending on the final sound of a preceding morpheme. The table below displays an overview of the alternations of initial consonants in the Amur dialect.

\begin{tabular}{|c|c|c|}
\hline preceding morpheme & \multicolumn{2}{|c|}{ following morpheme (head of construction) } \\
\hline final sound & initial sound (alternation set $\mathrm{A}$ ) & initial sound (alternation set B) \\
\hline plosive, vowel, glide $/ \mathrm{j} /, / \tilde{\mathbf{n}} /,(/ \mathrm{l} /)$ & voiceless fricative & voiced fricative \\
\hline fricative & \multirow{2}{*}{ aspirated plosive } & voiceless plosive \\
\hline nasals $/ \mathrm{m} /, / \mathrm{n} /, \mathrm{m} / ; / 1 /$ & & voiced plosive \\
\hline $\begin{array}{l}\text { determiner } \\
\text { verbal attributive form } \\
i-\left(3^{\mathrm{u}}\right) \text { and plural pronouns }\end{array}$ & aspirated plosive & voiced plosive \\
\hline $\begin{array}{l}\tilde{n}-(1 \mathrm{~s}) \\
t^{*}-(2 \mathrm{~s}) \text { and } p^{*}-(\mathrm{REFL}) \text { pronouns }\end{array}$ & voiceless & $\begin{array}{l}\text { voiced fricative } \\
\text { voiceless fricative }\end{array}$ \\
\hline
\end{tabular}

As a rule of thumb, the alternation patterns like dissimilation: after a plosive or vowel the fricative initial allomorph appears; after a fricative, it is the plosive initial allomorph. An example is:

$$
\begin{aligned}
& \text { citation form: ramzud 's.o. dropped s.th.'2 }
\end{aligned}
$$

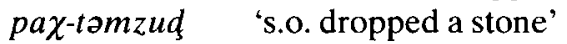

$$
\begin{aligned}
& \text { lep-romzud 's.o.dropped bread' } \\
& \text { nirn-dəmzud 's.o. dropped a [wooden] dish' (COMRIE 1981:267) }
\end{aligned}
$$

(iii) Singular pronouns trigger additional changes, as indicated in the table. If the morpheme to the left of the boundary is such a pronoun, its form is either reduced or determined by vowel harmony induced by the first vowel of the following lexical or inflectional morpheme. Additionally, the pronoun triggers initial consonant alternation of the following morpheme. Compare parts of the inflectional paradigm of the first person pronoun $\tilde{n} i$ (cf. PANFILOv 1968: 416-417) with possessive constructions with 1s possessor (cf. Austerlitz 1959: 106, 1990: 18; HATTORI 1988: 1412):

1 Transcriptions and glosses have been changed in most examples by me.

$2 / \mathrm{r} /$ and $/ \mathrm{T} /$ pattern like fricatives. 
(3) free form: $\tilde{n} i 1 \mathrm{~s}$ inflectional forms possessor-possessed $\tilde{n} i$ - $\gamma$ ir INS $\tilde{n} e-r \chi \mathrm{ALL}(<-r o x \mathrm{ALL})$ $\tilde{n} i$-flonk 'my ashes' $\tilde{n} e$-fla $k$ ' 'my leaf' ñe-s sařr'my tree' $\tilde{n}$-ax CAUSEE $\tilde{n}$-ro jo TERM

$\tilde{n}-u$ 'my cave' $\tilde{n}$-zom $\check{r}$ 'my leaf' $n$-lu 'my song'

The alternations described above do not show up just anywhere, but rather occur if the adjacent morphemes are in certain grammatical relations to each other: primary object and verbal root, adverbially modifying root and verbal root, attributive nominal or verbal root and nominal head, possessor and head noun, and determiner and head noun (as will be shown in detail in sections 5 and 7). In other words, they occur if two adjacent morphemes are in a government or modifying relationship, or, in NicHoLs's terms, if they are dependent and head. Furthermore, the alternations occur at the morpheme boundary of a lexical morpheme and a grammatical morpheme (number, case, focus, tense/aspectoid) or of two suffixes. For an example, compare the allomorphy of the 'highlighting focus' morpheme with example (2):

$$
\begin{aligned}
& -t a /\{\text { fricative }\}_{+} \\
& \sim-d a /\{\text { nasal, } / 1 /\}_{+} \\
& \sim-r a /\{\text { plosive, vowel, } / \mathrm{j} /\}+_{-}
\end{aligned}
$$

\section{Dependent-head synthesis and wordhood}

The morphophonemic alternations suggest a certain degree of synthesis of the adjacent morphemes. And indeed BONDARKo/ZINDER (1962) proved by experiment that there are chains of adjacent morphemes which form single accentual units. Their sonagrams show that in

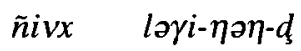

$$
\begin{aligned}
& \text { person salmon-hunt-IND/NML } \\
& \text { 'man catches salmon' }
\end{aligned}
$$

(BONDARKO/Zinder 1962: 89)

there are two peaks (not three), one on the [i] of $\tilde{n} i v x$ and the other on the [a] of loyi, which means that there are two accentual units. In

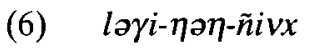

$$
\begin{aligned}
& \text { salmon-hunt-person } \\
& \text { 'salmon hunter' }
\end{aligned}
$$

(BONDARKO/ZINDER 1962: 89)

there is only one peak on the first [2]. In other words, the whole construction is one accentual unit. There are no morphophonemic alternations this time as an additional proof on the morphological level, since there are no critical consonants involved, but constructions involving morphophonemic alternations behave analogously (see BONDARKo/ZINDER 1962: 84-87). Krejnovič (especially 1937), Jakobson (1971), Nedjalkov/Otaina (1988: 136), WATANABE (1983: 63; 1992: 185, 188), and BondARKo/Zinder (1962) acknowledge that constructions in which the abovementioned relations hold are words, according to the con- 
ception that accentual units constitute phonological words (see for example NESPOR/VOGEL 1986: ch.4). PANFILov, however, although not disputing the accentual unity of the constructions, writes their elements as separate words because in his view words are not defined phonologically or morphologically, but are lexical-grammatical entities characterized by an independent, atomic meaning (1965: 23-30). Without discussion, most authors of Nivkh transcribed texts and grammatical sketches follow his example, so that accentual units are "invisible" in the absence of morphophonemic alternations.

In favor of the interpretation that dependent-head synthetic constructions like in (5) and (6) above are single words speaks their morphological cohesion. Nivkh phonological words are not interruptible and inflected as wholes: case or mood suffixes are only allowed at their end, not within, and take the synthesized elements in their scope. The order of the elements is rigid. Since accentual patterns, morphophonemic alternation domain and cohesion domain are coextensive, we could consider the emerging entities to be single words.

As an alternative to the recognition of single words, "phrasal sandhi" or the concept of "phonological phrase" (NESPOR/Vogel 1986: ch. 6) come in as handy interpretations, but are not adequate at a closer look. Sandhi processes apply within units greater than the word, but are largely phonologically conditioned, i.e. syntactically blind, and also depend on the register (cf. SPENCER 1996: 200-201). The phonological phrase (as described by NeSPOR/VoGEL 1986 ) is the domain of phonological phenomena which are both phonologically and syntactically conditioned, but the phonological phrase does not coincide with a constituent. In NESPOR/VOGEL's (1986) examples from Italian "raddoppiamento sintattico" and from French "liaison", the relevant domains for the phonological rules are the complexes [auxiliary-preverbal adverb-verb] and [quantifier or determiner-prenominal adjective-noun]. As the phonological rules are blocked if an attribute is postnominal, NESPOR/VOGEL claim that the domain of the phonological phrase consists of the head and all elements of its phrase on the non-recursive side (1986: 168). In Nivkh, however, morphophonemic alternations apply to domains containing the head and its recursive side, and they apply to VPs (verb and object) and NPs. Furthermore, as modifying or governed elements cannot stand to the other (right) side of their heads in Nivkh, there is no non-recursive side in the first place. Additionally, the Italian phonological phenomenon optionally applies even across syntactic constituent boundaries (NESPOR/VOGEL 1986: 172-173) and is thus partially syntactically blind, while the Nivkh rule applies strictly within phrases only, i.e., it is attentive to syntactic relations. In particular, Nivkh morphophonemic alternations apply between elements in a dependency relation only, i.e. not under coordination (cf. MatTISSEN/Drossard 1998: 53). On the other hand, this means that the domain of Nivkh alternations can be smailer than a syntactic counterpart, in which characteristic it again parallels the domain of the phonological phrase (NESPOR/VOGEL 1986: 41-42).

In their application to NPs and VPs, Nivkh alternations seem to be parallel to Celtic mutations, but in Welsh, for example, mutations are not phonologically conditioned (BALL/ MüLLER 1992: 4-5) and occur under non-adjacency in "VPs" (BALL/MülLER 1992: 146-160, $128,134,137)$, under both adjacency and non-adjacency in NPs, and they can be blocked by intervening elements (BALL/MüLLER 1992: 155, 161-163). Besides, in Nivkh the same alternations which apply to [object-verb] and [modifier-noun] apply to [lexical morpheme-inflectional suffix] as well, without any contention that these inflectional morphemes are bound. Welsh mutations within a word, however, i.e. under composition or inflection, are (because they are fortitions) different in type from mutations involving "VPs" and NPs, which are lenitions (cf. BALL/Müller 1992: 284-286). 
This leaves us with a systematic morphological and phonological synthesis of syntactically motivated constructions in Nivkh.

\section{Nivkh verb complex}

A first domain of dependent-head synthesis in Nivkh is the verb complex. A verb root synthesizes with (i) a noun bearing an object (or marginally other) relation to it and/or with (ii) another verb root modifying the verb root in an adverbial manner ${ }^{3}$ or functioning like a modal verb. The phenomenon under (ii) constitutes a kind of verb root serialization:

"Root serialization is formally different from verb serialization in as much as we find only combinations of verbal roots, which in most cases cannot form sentences on their own." (BISANG 1995: 177).

Here is a Yimas verb form for an example of this:

(7) impa-mpu-yakal-irim-tay-ntut.

3dlU-3plA-TAM-stand-see-REM.PST

'They stood watching them two.'

(FoLEY 1991: 179)

In Yimas, verb root serialization forms single words, as evidenced by inflectional affixes to both sides of the complex (FoLEY 1991: 278-279).

\subsection{Object-verb-synthesis}

Basically, Nivkh verbs can be divided into two classes: those which synthesize with a participant (a patient or a beneficiary/location) as evidenced by morphophonemic alternations (= (di)transitives), and those which do not (= intransitives). These two classes are distinguished formally by their verb-initial sounds. Nearly all intransitive verbs begin with a plosive (which does not alternate) or a vowel in their citation form. Transitive verbs begin with a fricative, $/ \mathrm{i} /, / \mathrm{e} /$, or $/ \mathrm{j} /$ (and do alternate).

$$
\begin{array}{llll}
o t-t & \text { 's.o. sews' (intr.) } & j-o t-\not & \text { 's.o. sews s.th./it' (tr.) } \\
t \text { ' } a-d, & \text { 's.th. roasts' (intr.) } & \check{r} a-d & \text { 's.o. fries s.th./it' (tr.) }
\end{array}
$$

Before furnishing an explanation for this, let us have a look at the morphosyntactic properties of transitive verbs. They obligatorily form a synthetic unit with their primary object if it is adjacent (cf. SAVEL'EVA/TAKSAMI 1970: 507), which is either pronominal (1st to 3rd person or reflexive) or nominal. The synthesized object saturates one place of the verb's valency and can represent one of the verb's arguments. There is no transitive verb without an object reflex. In other words, the object marker is a dependent which its head in fact requires, contrary to what NicHOLs (1986: 108) predicts. Its referential status ranges from generic as in (9) to fully discourse-referential (in the sense of being an antecedent for anaphoric reference, see (10)).

${ }^{3}$ There are no adjectives and only very few (non-synthesizing) adverbs in Nivkh, cf. MatTISSEN/DrosSARD (1998). 


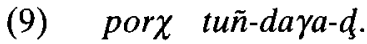

bar finger-thick-IND/NML

'The bar is as thick as a finger.'

(OTAINA 1978: 34)

(10)

$\begin{array}{llll}\text { hongut'umke } & m \bar{u} v \text {-ñaqr pal-rox } & \text { mar-ra } & q^{\prime} \text { otr-k'u-ra } \\ \text { living_thus } & \text { day-one_CLF mountain-ALL ascend-ENU:3s bear-kill-ENU:3s }\end{array}$

hosorot lar-yat-ra.

then 3U:divide-CPL-ENU:3s

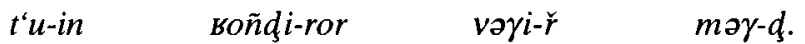

sledge-LOC 3U:load-CV:after 3U:drag-CV:3s descend-IND/NML

'Living thus, one day he went up into the mountain woods and killed a bear and then cut it fully up. He loaded it onto the sledge and dragging it along descended.' (BEFFA 1982: 87)

Pronouns, nominals, and the reciprocal prefix are mutually exclusive in the synthesized slot, i.e. there is only one slot in a complex verb form for a governed dependent.

Now, the initial /i, e, $\mathrm{j} /$ of (di)transitive verbs are the allomorphs of $i f$, the $3 \mathrm{~s}$ (free) pronoun, in the context of vowel or consonant cluster initial verbs and represent a 3rd person undergoer or an unspecific undergoer.

free form if ' $3 \mathrm{~s}$ '
inflectional forms
$i$-gir INS
$j$-ax CAUSEE
$e-r \chi \quad$ ALL

$\begin{array}{ll}\text { object-verb complex } \\ i \text {-vrəd } & \text { 's.o. tidies up s.th.' } \\ j \text {-aqtt } & \text { 's.o. cuts s.th.' } \\ e-m \chi a q u d & \text { 's.o. shortens s.th.' }\end{array}$

The fricative initials of verbs beginning with a single consonant can be considered the effect of consonant alternation of a plosive (plosive-initial roots being suggested by nonalternating intransitive verbs) due to a preceding vowel or glide which has been elided (cf. JAKOBSON 1971: 86; PANFILOV 1962: 41; HATTORI 1962). A nominal participant (see (12)) or a 1 st/2nd person pronoun (see (13)) are exchanged for the $3 \mathrm{U}$ markers $/ \mathrm{i}, \mathrm{e}, \mathrm{j} /$ and trigger adequate consonant alternation. If a noun root or $1 \mathrm{st} / 2 \mathrm{nd}$ pronoun synthesizes with a verb beginning with a fricative (instead of a $3 \mathrm{U}$ marker) the initial sound is subject to consonant alternation (see KREJNOvič 1934: 209):

$\begin{array}{ll}j \text {-urud } & \text { 's.o. reads s.th.' } \\ i-r l o d & \text { 's.o. pulls s.th.' } \\ \text { rad } & \text { 's.o. fries s.th.' } \\ & \\ & \\ \tilde{n}-z a-d & \text { 's.o. hit me' } \\ f^{\prime}-s a-d & \text { 's.o. hit you' } \\ p \text { '-sa-d } & \text { 's.o. hit self' } \\ z a-d & \text { 's.o. hit him/her/it/s.th.' } \\ \tilde{n} ə \eta-d g a-d & \text { 's.o. hit us' }\end{array}$

$\begin{array}{lll}: & \text { pityə-urud } & \text { 's.o. reads a book' } \\ : & k \text { 'e-xlod } & \text { 's.o. pulls a net' } \\ : & \text { ţus-t'ad } & \text { 's.o. fries meat' } \\ : & t^{\prime} o \text {-řad } & \text { 's.o. fries fish' }\end{array}$

free pronouns:

$\begin{array}{lll}\tilde{n} i & 1 \mathrm{~s} & \\ f^{\prime} i & 2 \mathrm{~s} & \\ p^{\prime} i & \text { 'self' } & \\ \text { (if } & 3 \mathrm{~s}) & \\ \tilde{n} \partial \eta & 1 \mathrm{p} & \text { etc. }\end{array}$

In these synthesized $\mathrm{N}-\mathrm{V}$ complexes the verb is the head of the construction and governs the noun, its object. The object is the patient of a transitive (see examples above) and the beneficiary or location of a ditransitive verb (note that the patient then is not case-marked): 
(14) objezdţ'ik $k^{\prime} e$ atak-asqam-d bay_watcher net grandfather-take_away-IND/NML 'The bay watcher took the net away from grandpa'.

(OTAINA 1978: 34)

(15) omək k'uva nux-t'a-d mother thread needle-insert-IND/NML

'Mother inserted a thread into the needle.'

free form: xed 's.o. inserts s.th.'

(PANFilov 1962: 126-127)

If atak 'grandfather' and nux 'needle' were not synthesizing, we should expect a $3 \mathrm{U}$ marker ( $j$ - and fricative initial, respectively) on the verbs.

As example (9) already suggests, synthesizing is not limited to POs but is possible with participants bearing a non-agentive subject, a manner or a locative relation to the verb (see also (35)):

$\tilde{n} a \gamma r \quad m \gamma e-d, \eta \neq k i-$
rat row-IND/NML tail-s
'The rat rowed, his tail rising
niv-so- $d$-ra
heart-ache-IND/NML-HILI
'My heart is aching.'

(KREJNOVIC 1934: 221)

'My heart is aching.'

(KREJNOVIČ 1960: 80)

Compare an alternative intransitive construction to (17):

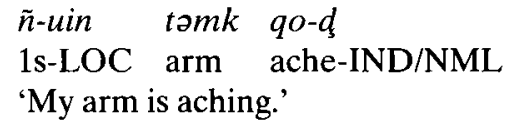

(Savel'eva/Taksami 1970: 143)

$\mathrm{Up}$ to this point, the findings look like noun incorporation. Noun incorporation is here understood to be the integration of nominal roots which can form free word forms into one accentual unit with otherwise free verbal roots (following GerDTs 1996). This excludes denominal verbs as in Greenlandic (free N, bound "V"), classificatory verbs or "lexical affixes" as in Caddoan languages (bound " $N$ ", free V), and "noun stripping" (no accentual unit, cf. GERDTs 1996: 93) as in Polynesian and Micronesian languages.

Nivkh object-verb synthesis is different from noun incorporation in three important respects. First, because of the integration of beneficiaries, as shown above. Secondly, the lexical range of possible "incorporees" is much broader than is usually the case in incorporating languages. Interrogatives (PANFILOv 1965: 23-25) and even proper names (see JAKOBSON 1971: 90, KREJNOvič 1934: 192, 193) synthesize with a verb, as is evidenced by morphophonemic alternations (contrary to what MITHUN 1984: 864 and SPENCER 1995: 453 observe):
a. $a \eta$
$\chi a-d$
vs.
who shoot-IND/NML
'Who shot at it?'

b. if

3s

$a \eta-q^{\prime} a-d$

'Who did he shoot at?'
a. Xor za-ñivx
$X$. hit-person
'the man Xor beat'

vs.

b. Xor-ḑa-ñiv $x^{4}$

$X$. -hit-person

'the man who beat Xor'

\footnotetext{
${ }^{4}$ The alternation reflects an elided final nasal (see JAKOBSON 1971: 90).
} 
Thirdly, nouns synthesizing with verbs are inflected neither for case nor for (highlighting or question) focus, but can be marked for (i) plural or comitative (which can be combined with case markers but not with number markers and thus behaves rather like number than like case) and (ii) suffixes expressing concepts parallel to KöNIG's (1991) "focus particles", i.e. 'only', 'even' etc. Again, morphophonemic alternations prove the synthesis, compare the free forms $t$ if 'path', ind $\partial d \sim-n$ ř $\partial d$ 's.o. sees s.th.', and ñivx 'person', $i \gamma d \sim-k$ 'ud 's.o. kills s.th.' with the forms printed in bold in the examples below:
$\tilde{n} i \quad \eta a q r-u x \quad k ' e q-x o \quad h o j k-x o-z i f-k u-n \check{r}$-d
1s snow-ABL fox-DCOM hare-DCOM-path-PL-see-IND/NML

'In the snow I saw the traces of foxes and hares.' (SAVEL'EVA/TAKSAMi 1970: 527)

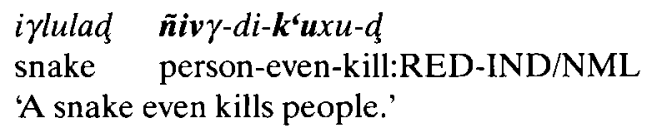

(PAnfilov 1965: 75)

Note in passing that in this, Nivkh is clearly different from noun-stripping languages, to which it seems to resemble if the accentual unity of dependent-head constructions is not acknowledged. At any rate, the object relation is encoded by an extensive dependent-head synthesis evidenced by morphophonemic alternations signalling the syntactic relation in the absence of central case-marking.

\subsection{Verb root serialization}

Dependent-head synthesis is not only operative in the case of a government relation, but also in the case of a modificational relation between two verb roots, with the preceding, uninflected one modifying the following, fully inflectable one in an adverbial way.

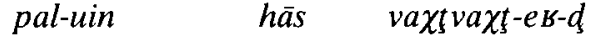

$$
\begin{aligned}
& \text { mountain-LOC clothes tear.tear-fast-IND/NML } \\
& \text { 'Clothes tear quickly in the mountain woods.' }
\end{aligned}
$$

(Panfilov 1965: 75)

(24) to-gan ve-ur-d

this-dog run-good-IND/NML

'This dog runs well.'

(KREJNOVIČ 1934: 220)
ţiv-ux
p'ro-ivu-ke
t'oluju-ra
mangla-laju-ra

path-ABL come-PROG-CV:while foggy-ENU:3s strong-stormy-ENU:3s

'While he went down the path it was foggy and a heavy storm was blowing.'

(PANFILov 1965: 181)

Note that the modifying elements are not adverbs but roots which can form free verbs. The few existing Nivkh adverbs form a closed class and never coalesce to anything. The exemplified construction is in fact a serialization of verbal roots (cf. BISANG 1995: 177) with each root contributing its full lexical meaning. Verb root serialization is rarer than objectverb synthesis, and more often an analytic construction containing an adverbial is met with:

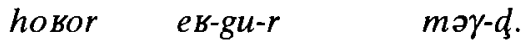

$$
\begin{aligned}
& \text { therefore fast-CST-CV:3s descend-IND/NML } \\
& \text { 'Therefore he descended quickly.' }
\end{aligned}
$$


Verb root serialization and its analytic counterpart in Nivkh are fairly parallel to the Chukchi situation:

a. nə-tur-tejk-əkinet nelg-ət

(verb root serialization)

$\mathrm{CHU}$ 3p.S-new-make-3p.O skin-PL 'They are making skins again.'

(SPENCER 1995: 455)

b. no-tur-ew no-tejk-əkinet nelg-ət

CST-new-CST 3p.S-make-3p.O skin-PL 'They are making skins again.'

(analytic)

(SPENCER 1995: 455)

The same principle of verb root serialization is exploited for the synthesis of verb root and modal verb root. This time, the lexical root precedes the modal verb root and can be inflected for causative and/or tense/aspectoid categories (cf. KREJNOvič 1934: 217-218; contrary to what BAKER 1996: 31-32 predicts).

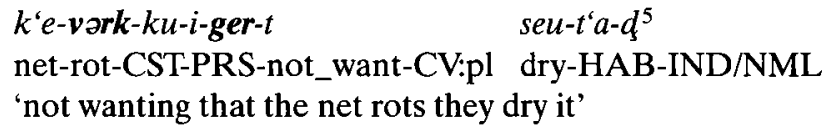

(Panfilov 1965: 162)

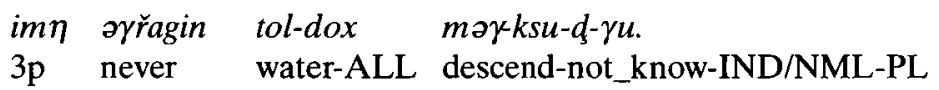

'They have never gone down to the water.'

(PANfilov 1965: 161)

Note that verb roots used as modal verbs exist as free verbs as well:

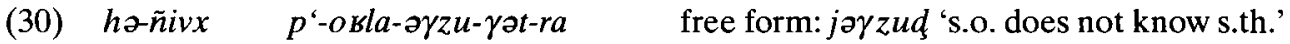
that-person REFL-child-not_know-CPL-HILI

'That person did not know his child at all.'

(Panfilov 1965: 71)

Part of the modal verbs are construed this way, others are used with a complement clause (cf. Panfilov 1965: 105, 162-163). Finally, reduplication in Nivkh takes the form of root or stem serialization. Incidentally, all reduplicative forms are written in one word by PANFILOV (1965: 74pp).

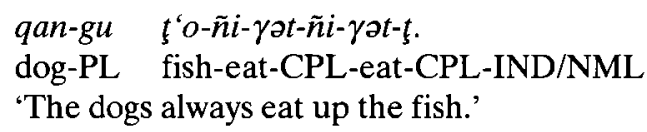

'The dogs always eat up the fish.'

(Panfilov 1965: 78)

In all cases of root/stem serialization mood inflection is only possible on the last root or stem, not within the synthetic unit.

\section{Is Nivkh a polysynthetic language?}

Object-verb synthesis and integration of adverbial and modal elements feature among the "ingredients" of polysynthetic languages, such as Greenlandic, Mohawk, Ket, etc. So it is worthwhile checking whether Nivkh fulfills any other polysynthesis criteria.

Although there is no ultimate definition of polysynthesis to date, there is a set of criteria

\footnotetext{
${ }^{5}$ Both word forms are written as one word by PanfiLov.
} 
largely agreed upon (Mithun 1988, ForTescue 1994, BAKER 1996, Drossard 1997), according to which a polysynthetic language is basically characterized by

(i) "word-sentences", i.e. complex word forms which translate as whole sentences into other languages because they comprise encoding of a predicate's arguments (polypersonalism), adverbial concepts, and what would be auxiliaries in more analytic languages, and optionally noun incorporation

(ii) complex verb forms featuring a high number of morphemes or potential slots per word

(iii) morphology playing a prominent role due to the existence of a fair amount of bound morphemes with rather concrete ("lexical") meaning, and a significant entanglement of derivation and inflection.

In addition to what was presented above, a Nivkh verb complex has a range of potential slots, most of which need not be (and usually are not) filled (cf. ForTESCUE 1994: 2601):

(32) (primary object)-(serial slot-(causative)-(temporal/aspectoid suffix))-verb root (TR)(aspectoid suffix)-(causative)-(temporal/aspectoid suffix)-(modality)-mood/focus/ converbal suffix-((PL)-(“focus particles"/highlighting focus)) (auxiliary)

A fairly complex form where Nivkh circumstances are concerned features in the example below.

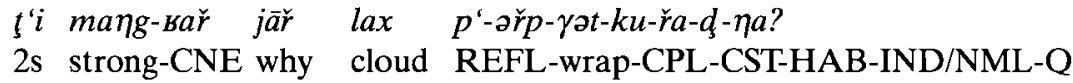

'If you are strong, why do you let clouds wrap you up?'

(Panfilov i965:78)

Besides phases of states of affairs and modal concepts (as exemplified in section 5.2), locational elements (which are bound morphemes) are encoded within a verb form, as would be expected of a polysynthetic language:

(34) mu-he-t $-t$ free form: jett 'pull s.th. out of the water' boat-water $\rightarrow$ riverside-pull-IND/NML

's.o. pulls a boat up onto the riverside (out of the water)'

(KREJNOVIČ 1960:86)

(35) mu t'as-k' $u-d$ ?

boat where-located-IND/NML

'Where is the boat?'

$\left.k^{\prime} u d\right\} \sim x u d$ 'be located'

(KREJNOVIC 1986:160)

Finally, productive word formation operates on the basis of recursive chaining of nominal and verbal roots (with the products written as single words by PANFILov 1965).

a. $\eta a-\eta \partial \eta-\tilde{n} i v x$

beast-hunt-person

'hunter'

(KREJNOVIČ 1934: 196)

b. poi-mu-meñ-vo-ñivx

fly-boat-helm-take-person

'pilot'

(JAKOBSON 1971: 80) 
c. pəi-urla-ləx

fly-good-weather

'good weather for flights'

(SAVEL'Eva/Taksami 1970: 170)

An entanglement of derivation and inflection is visible particularly in the systematic ambiguity of nominalizing and "indicative" $d$-form. On the one hand, the morpheme $d$ s on verbs makes them compatible with all nominal inflection. This mechanism is fully productive, but a range of those nominalized forms have been lexicalized (cf. PANFILOv 1962: 69).

$\begin{array}{llll}\text { nəd } & \text { 'do'; 'doing' } & \text { nəd, } & \text { 'deed, work' } \\ \text { humd } & \text { 'be there, live'; 'living' } & \text { humd } & \text { 'life' } \\ \text { lerd } & \text { 'play'; 'playing' } & \text { lerd } & \text { 'game' } \\ \text { tolad } & \text { 'poor'; 'being poor' } & \text { tolad } & \text { 'poverty' } \\ \text { iñd } & \text { 'eat'; 'eating' } & \text { iñd } & \text { 'food' } \\ \text { mud } & \text { 'die'; 'dying' } & \text { mud, } & \text { 'dead person' } \\ \text { qalad } & \text { 'green; envy'; 'being green' } & \text { qalad } & \text { 'vegetables, greenery' etc. }\end{array}$

On the other hand, the $d$-form of verbs is the most frequently occurring matrix predicate form of any verb, in a paradigm with other mood forms, and is therefore glossed IND/NML here. It is still compatible with nominal number and focus suffixes, but is not case-marked. In contrast to nominal predicates it can bear additional modal markers (like -rej indicating mocking surprise of the speaker).

$$
\begin{aligned}
& \text { if } \quad \text { vi-d-rej } \\
& 3 \mathrm{~s} \text { go-IND/NML-REJ } \\
& \text { 'He is gone.' (in a mocking surprise) }
\end{aligned}
$$

(BEFFA 1982: 82)

This systematic ambiguity of a $d$-form leads to the possibility of various interpretations for one and the same construction (cf. PANFILOV 1965: 67-68):

$$
\begin{array}{lll}
\text { if } & \text { hum-d } & \text { həjm-d } \\
\text { 3s } & \text { be_there-IND/NML } & \text { know-IND/NML }
\end{array}
$$
a. 'he knows life'
(humd 'life')
b. 'he knows the one who is there' ( uumd 's.o. is there')
c. 's.o. knows that he/she lives, is there'
(if humd 'he/she lives, is there')

Finally, demonstratives are formed from deictic roots $+-d$ and are inflected like nouns: ho- 'that', hod 'that one', etc.

Up to this point, Nivkh seems to resemble polysynthetic languages to a sufficient degree. But the range of concepts encoded within a polysynthetic verb form, namely manner, degree, chronology, quantification, etc. (see Mithun (1988: 443), Fortescue (1994: 2602), and DrosSARD (1997)), is not reached in Nivkh. Nor does Nivkh have classificatory elements (for type of action or type of participants) like Iroquoian. The most intriguing problem is, however, that Nivkh, strictly speaking, lacks polypersonalism. As we saw in section 5.1., the object is obligatorily encoded on the verb, but the finite mood forms are not marked for their subject (as in (39)), except in the imperative. The subject is marked, however, on two classes of verb forms:

(i) on the most frequent matrix form, the $d$-form, in the form of (non-obligatory) number agreement

(ii) on one class of converbs through person marking. 
The most frequent matrix predicate form, "indicative" - $d$-form, usually bears the nominal plural suffix if its subject is human plural, thus cross-referencing the subject.

$\begin{array}{llll}t \partial-\tilde{n} i v \gamma-g u & m u-t^{\prime} o m-\gamma i r & f^{\prime} 0-\eta \ni \eta-d-\gamma u & h a d-\gamma u \\ \text { this-person-PL boat-5_CLF-INS } & \text { fish-hunt-IND/NML-PL that_one-PL }\end{array}$

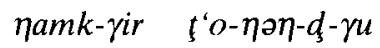

(PANFILOV 1962: 192)

seven-INS fish-hunt-IND/NML-PL

'These people went fishing in five boats, those went fishing in seven.'

Nivkh converbs form two classes: those which encode their subject and those which do not. The subject marker is $-t$ or $-t a$ (depending on the converb) cross-referencing $1 \mathrm{~s}, 1 \mathrm{p}, 2 \mathrm{p}$, and $3 \mathrm{p}$, and $-r$ or $-r a$ cross-referencing $2 \mathrm{~s}$ and $3 \mathrm{~s}$.

$\begin{array}{lllll}\tilde{n} i & m \gamma e-t a, & t^{\prime} i & m e \tilde{n}-v o-r a & h a-j a \\ 1 \mathrm{~s} & \text { row-ENU:1s } & 2 \mathrm{~s} & \text { helm-take-ENU:2s } & \text { be_so-IMP.s }\end{array}$

'Let me row and you take the helm.'

(TAKSami/Polet'eva 1992: 50)

The enumerative converb, which is exemplified in (41) together with a form of the dummy matrix predicate had 'be so' (inflected for mood) at the end of the clause chain, is more often than not used without this dummy and then looks like an independent mood form (see (42), after which BefFa put a full stop).

\begin{tabular}{|c|c|c|c|c|}
\hline $\begin{array}{l}\text { honguţ'umke } \\
\text { thus_living }\end{array}$ & $\begin{array}{l}\text { aţik } \\
\text { younger_brother }\end{array}$ & $\begin{array}{l}\text { ork } \\
\text { already }\end{array}$ & $\begin{array}{l}\text { pil-ra } \\
\text { big-ENU:3s }\end{array}$ & $\begin{array}{l}\text { pal-rox } \\
\text { mountain-ALL }\end{array}$ \\
\hline & $a j-x u-r a$ & tox & & 'u-ra. \\
\hline
\end{tabular}

go_up-ENU:3s deer-kill-ENU:3s moose-kill-ENU:3s bear-kill-ENU:3s

'Living thus the brother was already big and he went up into the mountain woods and killed deer, moose and bears.'

(BEFFA 1982: 86)

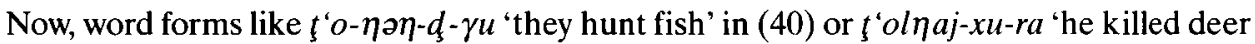
and' in (42), with both object-verb synthesis and a subject marker, look quite polypersonal. And what is more, the object and subject markers together form a bracket around the whole construction, contributing to its wordhood. Maybe we are witnessing polypersonalism in statu nascendi in Nivkh.

But even with polypersonalism being absent, a language can be polysynthetic. Whereas MITHUN (1988: 446-447), BAKER (1996: 14), and ForTESCUE (1994: 2601) more or less require a polysynthetic language to be head-marking or double-marking, DrosSARD (1997: 252) allows for what he calls "non-sentential" verb complexes as in languages like Haida, Tlingit or Awtuw. In these languages, the verbal word does not constitute a minimal sentence and lacks participant cross-reference (participants have to be encoded at least in the form of free pronouns). Nivkh is somewhere in between both extremes, as the verbal word does constitute a minimal sentence while neither being polypersonal, nor overt expression of participants being obligatory. Thus, the polypersonalism criterion is itself questionable and does not exclude Nivkh from polysynthetic languages.

At any rate, polysynthesis is understood to be a phenomenon rotating around a verbal complex only. In Nivkh, however, there is dependent-head synthesis with both verbal and nominal heads. 


\section{Nivkh nominal complexes}

While the ideas on polysynthetic verb complexes are fairly congruent, there is no unanimity as to what nominals should be like in polysynthetic languages. MithUN, working on American Indian languages, points out that nouns are generally not inflected for number, gender, or case, and that there are no obligatory NPs or number agreement (1988: 444). BAKER, restricting the domain of polysynthesis considerably (and excluding languages such as Greenlandic; $1996: 18-20$ ), adds that word order is free and that there are no true quantifiers or determiners in polysynthetic languages. Nichols (1986: 105) explicitly states that "there are no polysynthetic nouns", relegating complex noun forms in languages like Eskimo, Algonkin, Sioux, and Iroquoian to word formation, and considering the "adjectivenoun" relation to be "least prone to be head-marked" (1986: 76). ForTESCUE, on the other hand, recognizes incorporation of adjectival stems into nouns and marking of the possessor on nouns as polysynthesis criteria (1994: 2601), particularly with Greenlandic in mind.

The structure of Nivkh nominal forms is closer to what ForTESCUE describes, but does not involve bound morphemes with fairly concrete "adjectival" meaning as Greenlandic does (-(r)suaq- 'big' cannot form a word on its own; see FoRTESCUE 1984: 297, 317-318),

(43) siursus-suaq tassa kisi-mi

GRE rushing_sound-big COP:that_is alone-P'OR:4s

'A great rushig sound, that alone (was heard).'

(FoRTESCUE 1984: 31)

but rather roots which, otherwise, can form word forms on their own. These lexical roots enter into dependent-head synthetic forms with a noun being the head of the construction. Evidence for their synthesis lies in the fact that at the morpheme boundaries of adjacent determiner and noun, possessor and possessed, quantifier and noun, or modifying nominal or verbal root and noun the same morphophonemic alternations occur which we observed with verbal roots as heads, and in the fact that the synthetic forms are accentual units (see (6)) which are inflected as wholes and in which the order of elements is rigid. There is no possessor case or attribute marker. In other words, there is an equally strong dependenthead synthesis in verbal and nominal complexes. Austerlitz (1959: 103) proves that there is indeed a difference between one or two accentual units with nominal heads:
a. $\tilde{n}-\partial t x$
(possessive construction: one accentual unit)
1s-old_man
'my old man'
b. $\tilde{n} i \quad \operatorname{atg}_{3} x$
1s old_man
'I, the old man'
(appositive construction: two accentual units)

Examples for synthesis with various elements follow:

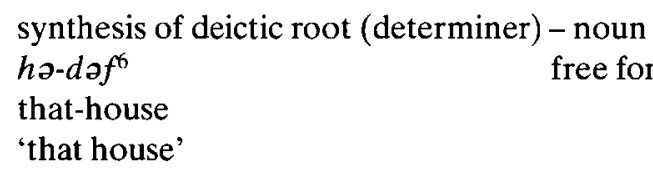

(KREJNOVIČ 1966: 39)

${ }^{6}$ Alternation is induced by a final elided nasal of the deictic element, compare the Sakhalin dialect variant with the nasal still present in (54). 
(46) synthesis of pronominal possessor - possessed (compare (13))

$\begin{array}{lll}\tilde{n} \text {-zaqo } & \text { 'my knife' } & \text { free form: ţaqo 'knife' } \\ t^{\prime} \text {-saqo } & \text { 'your knife' } & \\ p \text { '-saqo } & \text { 'one's own knife' } & \\ i \text {-dgaqo } & \text { 'his/her knife' } & \end{array}$

$\tilde{n} \partial \eta$-ḑaqo 'our knife' etc.

(KREJNOVIČ 1934: 205)

(47) synthesis of demonstrative pronoun possessor - possessed

həd_raf free form: $t$ of 'house'

that_one-house

'the house of that person'

(KREJNOVIČ 1966: 39)

(48) synthesis of numeral - noun

nax-kumusk

six-ruble

'six rubles'

(KREJNOVIČ 1934: 204)

(49) synthesis of quantifier - noun

huin $s \ni k-r u-\gamma u \quad v z u-d$ free form: $t u$ 'lake'

there all-lake-PL deep-IND/NML

'All the lakes there are deep.'

(OTAINA 1978: 61-62)

(50) synthesis of interrogative - noun

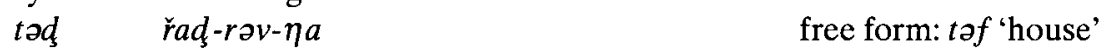

this_one who-house-Q

'Whose house is this?'

(Campbell 1991: 1015)

(51) synthesis of modifying noun stem - head noun

$q^{\prime}$ otr-ţif 'bear track'

$k^{\prime} e q$-zif 'fox track'

qan-dif 'dog track'

free form: tif 'path, track'

(KREJNOVIC 1958: 30)

(52) synthesis of proper name possessor - head noun

Sarat-rəf 'Sarat's house'

Seus-tof 'Seus' house'

free form: tof 'house'

(KREJNOVIČ 1934: 193)

(53) synthesis of modifying verb stem - head noun
Nosk
urla-can-da
free form: qan 'dog'

N. good-dog-HILI allomorphy of HILI see (4)

'Nosk is a good dog.'

(JAKOBSON 1971: 96)

Note that the verb stem is perfectly parallel to the one used in verb stem serialization. Synthetic forms can even be more complex by comprising several of the above determiners and modifiers.

(54) hun-tleulan-t “ ${ }^{\prime} \mathrm{r}^{7}$

that-white-hill

'that white hill'

(JAKOBSON 1971: 80)

${ }^{7}$ This is an example from a Sakhalin dialect, in which there are no voiced plosives. 
(55) $\tilde{n}$-yola-gəlmr

1s-long-board

'my long board'

(56) $\quad p^{\prime}$-loţi-bitya

REFL-Russian-book

'self's Russian book'

(57) hə-namg-ñivx

that-seven-person

'those seven people'

(58) $\tilde{n}$-ətək-rəf

1s-father-house

'my father's house' free forms: kald 'long', kalmr 'board'

(KREJNOVIČ 1958: 31)

free form: pityo 'book'

(KREJNOVIČ 1934: 194)

(Panfilov 1965: 80)

free forms: tof 'house', $\tilde{n} i$ 1s

(KREJNOVIČ 1934: 193)

From the above evidence we can conclude that a nominal complex in Nivkh looks like this:

(59) (determiner/possessor ${ }^{\mathrm{n}}$ )-(quantifier)-(attribute)-nominal root-(number)-case-("focus particles"/highlighting or question focus)

Dependent-head synthesis is obligatory with nominal heads, i.e. it is not possible to rephrase the above constructions analytically.

Nivkh dependent-head synthesis results in "word-phrases", i.e. complexes corresponding to phrases in more analytic languages, rather than in "word-sentences" as polysynthesis does (although they do occur). A nominal synthetic complex as presented in this section can form the dependent of an object-verb synthetic complex as in the following examples (observe morphophonemic alternations at the boundaries):

(60) $\tilde{n} ә \eta$-asq-rəu-ja!

1p.EXCL-younger_sibling-teach-IMP.s

'Teach our younger sibling!'

$$
\text { raud -təud 'teach' }
$$

(JAKOBSON 1971: 79)

(61) t'a to-q'av-la-t'ax-ta-ja!

PROH this-hot-LA-water-drink-IMP.s

'Don't drink this hot water.'

t'ax -sax 'water', rad -tad 'drink'

(Panfilov 1968: 430)

$\begin{array}{ll}t^{*} \text {-vila-gan } & \text { ева-ḑuz-ñi-ḑ } \\ \text { 2s-big-dog } & \text { cow-meat-eat-IND/NML }\end{array}$

'Your big dog ate (the) beef.'

free forms: $\frac{t}{\text { ' }} \mathrm{c} 2 \mathrm{~s}$ ', $\quad$ pild 'big', qan 'dog', ева 'cow', ţus 'meat', iñd 'eat'

(KREJNOVIČ 1934: 194)

(63) $\tilde{n} i \quad m u-l \partial t-i v u-\tilde{n} i v x-n \check{\partial} \partial-d$ 1s boat-make-PROG-person-see-IND/NML

'I saw a man building a boat.'
(PAnfilov 1965: 77)

As is evident from the last example, this construction type also comprises what would be relative clauses (also complement clauses) in more analytic languages. In this, Nivkh again differs from noun-stripping languages, in which modification and determination of a stripped ("incorporated") noun are impossible (cf. RosEN 1989).

Dependent-head synthesis as in Nivkh has not been dealt with in detail so far. Nevertheless, it is not a unique trait of Nivkh. 


\section{Dependent-head synthesis in other languages of the Far Northeast}

A syntactic organization very parallel to Nivkh is found in at least two other languages, which are not too distant from Nivkh geographically, namely Chukchi and Ainu. Chukchi is a member of the Chukcho-Kamchadal family which is also subsumed under Paleosiberian languages but not actually genetically related to Nivkh; Ainu is a language isolate formerly spoken on Hokkaido, the Kuril islands, and Sakhalin. At least Nivkh and Ainu have been in contact for some while in the course of their history. Chukchi and Ainu are considered polysynthetic by BaKer (1996: 19-20; see especially ShiBatani 1990: 17 for Ainu). Both languages manifest polypersonal complex verb forms with noun incorporation, verb root serialization, and integration of adverbials and various grammatical categories (SPENCER 1995: 444-448, 455-459; Shibatani 1990: 60-76, 80; BAKER 1996: 37 (fn. 26)), as well as complex noun forms, which we will concentrate on here.

In Chukchi, a determiner, a possessive pronoun, a wh-word, a quantifier, and a noun or verb root can be incorporated recursively into a nominal word form, and this mechanism is described as even more productive than noun incorporation by SPENCER (1995: 477, 479-480). Such a nominal complex is subject to vowel harmony (very grossly low vowels of "dominant" morphemes triggering harmony of high ones, cf. SpENCER 1995: 445) in the same way as a noun-incorporating verbal complex (SPENCER 1995: 478), and is inflected as a whole, with inflectional circumfixes ultimately proving the wordhood of both the nominal and the verbal complexes.

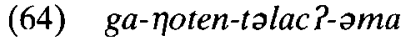

CHU COM-this-motor-COM 'with this motor'

(65) morəg-klass-ək

CHU our-class-LOC 'in our class'

(66) ga-neran-wag-ma

CHU COM-two-claw-COM 'with two claws'

(67) req-upicgən

CHU what-pole 'what pole'

(68) $\quad \eta$ inqej-kPeli

CHU boy-cap 'a boy's cap'

(69) ga-tan-pojgə-ma

CHU COM-good-spear-COM 'with a good spear'

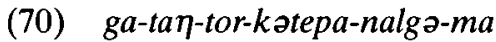

CHU COM-good-new-ram-skin-COM 'with a good, new, ram's skin' (integration of determiner)

(SPENCER 1995: 479)

(integration of possessor)

(SPENCER 1995: 479)

(integration of numeral)

(SPENCER 1995: 479)

(integration of wh-word)

(SPENCER 1995: 477)

(integration of nominal modifying root)

(SPENCER 1995: 477)

(integration of verbal modifying root)

(SPENCER 1995: 478)

(recursive integration of modifying roots)

(SPENCER 1995: 480) 
Corresponding analytic phrases can be construed by deriving regular relational forms of modifying nouns, $w h$-words, and verbs (SPENCER 1995: 477):

(71) a. arm-a Paçek

CHU strong-youth

(N-complex)

b. n-erme-qin apaçek (paraphrase)

PART-strong-PART youth

'a strong young man'

(SKORIK 1961, I: 427)

In Ainu, at least possessors, quantifiers, and modifying noun or verb roots are integrated into a nominal complex and can be recursive. Evidence for wordhood is of an accentual and a morphophonemic nature: assimilation and dissimilation phenomena of final and initial sounds, a reduced form of vowel harmony, and the systematic avoidance of a hiatus (SHIBATANI 1990: 74-75, 13).

(72) ku-pon-turesi

AINU 1sS-little-younger_sister

'my little sister'

(Shibatani 1990: 73)

(73) k-arka-sikihi

AINU 1s-hurt-eye

'my hurting eye'

(Shibatani 1990: 73)

(74) usa-oruspe

AINU various-rumor

'various rumors'

(Shibatani 1990: 72)

(75) e-pon-no-poro-setaha

AINU2s-slight-ADV-big-dog

'your slightly big dog'

(Shibatani 1990: 74)

Analytic constructions are generally possible and manifest a different order of elements and no limitation on the number of modifiers (SHIBATANI 1990: 74), thus a single word complex and a phrase are distinguished.

\begin{tabular}{|c|c|c|}
\hline (76) pon & akor & sapo a-at-e-uk \\
\hline AINU young & 1s.P'OR & sister PASS-rope-APPL-tie \\
\hline 'My yo & d up with a rope.' & (Shibatani 1990: 68) \\
\hline (77) ponno & poro & e-setaha \\
\hline AINU slightly & big & 2s.P'OR-dog \\
\hline
\end{tabular}

Except for the possibilities of analytic constructions, Chukchi and Ainu phrasal organizations are parallel to Nivkh. For Chukchi, furthermore, there are examples of a whole nominal complex being incorporated into a verbal complex (SPENCER 1995: 480). Here again, inflectional circumfixes and vowel harmony constitute evidence for the wordhood of this construction.

(78) ta-7oron-qora-kən?o-rkən

CHU 1sS-three-stag-catch-1s.PRS

'I'll catch three stags.'

(SKORIK 1961, I: 102) 
(79) ta-tor-ta $\eta$-polwəntə-pojgə-pela-rkən

CHU 1sS-new-good-metal-spear-leave-1s.PRS

'I am leaving a good, new, metal spear.'

(SPENCER 1995: 480)

In Ainu, only bare noun roots can be incorporated (SHIBATANI 1990: 71), but a noun root and an adverbially modifying root can be incorporated at the same time (SHIBATANI 1990: 72).

(80) pinne kamuy kiraw-riki-kur-roski

AINUmale god horn-high-EXPL-raise

'The male (dragon) god raised the horns high.'

(Shibatani 1990: 72)

All in all, with noun incorporation, verb root serialization, and complex noun forms Chukchi and Ainu display (to different extents) a range of syntactic parallels to Nivkh.

Outside Siberia, noun-attribute synthesis is attested as well: MITHUN cites an example from the incorporating language Tupinambá, mentioning that there are no "separate adjective-noun sequences", i.e. no analytic constructions (1984: 857).

\section{Typological classification}

In conclusion, we have observed dependent-head synthesis as the basic principle of Nivkh syntactic organization. Dependent and head are adjacent morphemes at whose common boundary morphophonemic processes are operative, with the final and initial consonants of morphemes being different in absolute final or initial position and in bound position, respectively. The synthetic forms are accentual units inflected as wholes. Within the complexes only a limited range of inflectional categories can be specified. Dependent-head synthesis is operative in government and modificational relations between a head and a dependent, i.e. in the following relations:

$\begin{array}{ll}\text { dependent } & \text { head } \\ \text { primary object } & \text { predicate } \\ \text { adverbial modifier (verb root) } & \text { verb } \\ \text { verb } & \text { modal verb } \\ \text { determiner } & \text { noun } \\ \text { quantifier } & \text { noun } \\ \text { possessor } & \text { possessed } \\ \text { modifying noun root } & \text { noun } \\ \text { modifying verb root } & \text { noun }\end{array}$

Two distinct dependent-head synthetic complexes can be distinguished on the basis of their heads and slots, each of which offers slots in a fixed order for dependents in two different relations to the head:

(81) a. object-serial slot-V-TAM inflection

b. determiner/possessor-quantifier-attribute-N-number/case/focus inflection

The last lexical root in a synthetic form is the head of the construction and determines the type of inflection. Structurally, the dependent-head complexes correspond to phrases in more analytic languages. Since the subject is not consistently integrated into dependenthead synthesis (i.e. there is no fully grammaticalized polypersonalism), it results in "word- 
phrases" rather than "word-sentences". From the point of view of function, both synthetic constructions in Nivkh serve equally well as predicates and as arguments. ${ }^{8}$

The synthesis of heads and dependents in Nivkh signals the existence of a dependent-head relation without specifying the kind of the relation. Within Nichols' typology of head/dependent-marking, Nivkh must be classified as head-marking, along with noun incorporation and polysynthesis (which Nichols, without further discussion, counts as headmarking). The synthesis is head-marking in the sense that the dependent is fully specified on the head. Nichols herself recognizes a "head-marked pattern" in connection with "sandhi" in Nivkh (= Gilyak) (1986: 100), but overlooks the importance of this pattern and thus considers the language "largely isolating" on the whole. Even disregarding the phenomenon discussed here, Nivkh has a considerable amount of morphology and is more agglutinating than isolating.

So Nivkh manifests a head-marked pattern and a high degree of synthesis, with a range of phenomena reminiscent of polysynthesis. Is there a relation between this type of dependenthead synthesis and polysynthesis?

The common denominator of all languages which have been described as polysynthetic is a complexity of verb forms with integration of material that forms separate constructions in more analytic languages. Apart from that, the languages exhibit quite different sets of criteria which apply out of the pool of polysynthesis ingredients (compare typologies of DrosSARD 1997 and FORTESCUE 1994), with some features more salient than others. In this sense, BAKER (1996: 338) observes that languages with rich noun incorporation are "poor(er) in other complex predicates" (e.g. Mohawk) and vice versa (e.g. Yimas, which has verb root serialization but no noun incorporation). Viewed from this angle, Nivkh could be specialized in yet another way. As we have seen, it does not stand alone, but shares a considerable range of organizational characteristics with Chukchi and Ainu, two languages of its wider geographical region. The three languages manifest (to different degrees):

(i) a dependent-head noun-verb synthesis close to "compound noun incorporation" in the sense of Rosen (1989)

(ii) complex forms around a nominal head, with synthetization of modifiers and determiners

(iii) synthetization of complex noun forms with verbs

(iv) synthetization of verbs with adverbial and modal elements via verb root serialization.

In contrast especially to American Indian polysynthetic languages they exhibit:

(v) a moderate number of potential or filled verb slots

(vi) a low number and small variety of bound morphemes (vs. Greenlandic)

(vii) an absence of classificatory verbs (verbs including a bound (not a lexical) element characterizing the type of participant involved) (vs. Mohawk).

Chukchi and Ainu have been classified as polysynthetic languages elsewhere, and the difference to Nivkh seems to be rather one of degree than of kind. Besides, Nivkh fits into the polysynthesis classification by Drossard (1997: 262):

${ }^{8}$ Converbs and verbs in mood forms (except the $d$-form) serve as predicates only. 
There is integration of adverbial concepts (which is a necessary and sufficient condition), the verb form is sentential (vs. polysynthetic languages such as Awtuw) though not polypersonal, and there is integration of nominal concepts (vs. Yimas). Integration of nominal concepts is in the form of a lexical noun root (not a bound element like in Quileute) incorporated into a lexical verb root (not a bound one like in Eskimo).

Approaching the question of relatedness of various forms of synthesis from another perspective, we could try and establish a typology of factors bringing about a high degree of synthesis in different languages, which cluster in various ways to be constitutive of polysynthetic, incorporating, or verb root serialization languages. The polysynthesis typology by FORTESCUE (1994: 2602) could serve as a basis, which enlarged and rearranged to a classification of synthesis parameters reads as follows:

A high degree of morphological synthesis in a language can come about by way of

A: derivation, taking the form of

(i) a complex verb form characterized by a multitude of fixed slots which need not all be filled at once (usually including classificatory verbs), e.g. Navajo, Haida, Awtuw, Ket

(ii) a complex verb form or noun form resulting from recursive affixing out of a pool of a multitude of bound morphemes with lexical and grammatical content (including denominal verbs), e.g. Eskimo, Kwakwala

B: composition, taking the form of a complex verb form or noun form resulting from integration of otherwise lexeme-forming morphemes, with the subtypes

(i) noun incorporation only

(ii) noun and verb integration into each other (noun incorporation and verb root serialization)

(iii) verb root serialization only

(Mohawk, Onondaga)

(Chukchi, Ainu, Nivkh)

(Yimas)

Languages may exhibit several of these parameters at the same time, for instance, Mohawk has classificatory verbs as well as noun incorporation and some verb root serialization (cf. BAKER 1996), Chukchi and Nivkh have noun incorporation/synthesization, verb root serialization, and some denominal verbs (cf. SPEnCER 1995: 462, MatTissen/Drossard 1998: 64), but Yimas and Greenlandic stick to one parameter only. If a language has noun incorporation only or verb root serialization only, it shows synthetic traits but in my view does not qualify as polysynthetic.

All in all, we have observed a syntactic organization in Nivkh which seems intermediate between languages where syntax is more prominent than morphology in phrase/clause constitution (e.g. European languages) and languages where morphology is more prominent than syntax (e.g. Iroquoian languages).

\section{Abbreviations}

$\begin{array}{llll}\text { A } & \text { agent } & \text { INS } & \text { instrumental } \\ \text { ABL } & \text { ablative } & \text { LA } & \text { morpheme -la- } \\ \text { ADV } & \text { adverb marker } & \text { LOC } & \text { locative } \\ \text { ALL } & \text { allative } & \text { NML } & \text { nominalization }\end{array}$




$\begin{array}{llll}\text { APPL } & \text { applicative } & \text { NOM } & \text { nominative } \\ \text { CHU } & \text { Chukchi } & \text { O } & \text { object } \\ \text { CLF } & \text { classifier } & \text { PART } & \text { participle } \\ \text { CNE } & \text { counter-expectative converb } & \text { PASS } & \text { passive } \\ \text { COM } & \text { comitative } & \text { PL } & \text { plural } \\ \text { COP } & \text { copula } & \text { PO } & \text { primary object } \\ \text { CPL } & \text { completive } & \text { P'OR } & \text { possessor } \\ \text { CST } & \text { causative } & \text { PROG } & \text { progressive } \\ \text { CV } & \text { converb } & \text { PROH } & \text { prohibitive } \\ \text { DCOM } & \text { distributive-comitative } & \text { PRS } & \text { present } \\ \text { ENU } & \text { enumerative converb } & \text { Q } & \text { question marker } \\ \text { EXCL } & \text { exclusive } & \text { RED } & \text { reduplication } \\ \text { EXPL } & \text { expletive } & \text { REFL } & \text { reflexive } \\ \text { FOC } & \text { focus marker } & \text { REJ } & \text { modal marker } \\ \text { GRE } & \text { Greenlandic } & \text { REMPST } & \text { remote past } \\ \text { HAB } & \text { habitual } & \text { S } & \text { subject } \\ \text { HILI } & \text { highlighting focus } & \text { TERM } & \text { terminative } \\ \text { IND/NML } & \text { indicative/nominalization } & \text { TR } & \text { transitivizer } \\ \text { IMP } & \text { imperative } & \text { U } & \text { undergoer }\end{array}$

\section{References}

AUSTERLITZ, Robert (1959): Semantic components of pronouns systems: Gilyak, in: Word 15 (1): $102-109$.

-(1990): Typology in the service of internal reconstruction: Saxalin Nivx, in: LeHMANN, WINFRED P. (ed.), Language Typology 1987: Systematic Balance in Language. Amsterdam: Benjamins. 17-33.

BAKER, MARK C. (1988): Incorporation. Chicago: Chicago University Press.

- (1996): The Polysynthesis Parameter. New York etc.: Oxford University Press.

Ball, Martin J./Müller, Nicole 1992: Mutation in Welsh. London: Routledge

Beffa, Marie-Lise (1982): Présentation de la Langue Nivx suivie de l'analyse linguistique d'un paragraphe du conte, in: Etudes mongoles et sibériennes 13: 49-98.

BISANG, WALTER (1995): Verb serialization and converbs - differences and similarities, in: HaSPELMATH, Martin / König, Ekkehard (eds.), Converbs in Cross-Linguistic Perspective. Berlin: Mouton de Gruyter. 137-188.

BondARKo, L. V. / ZiNDER, L. R. (1962): Fonetičeskaja xarakteristika različnyx tipov sintaksičeskix sočetanij v nivxskom jazyke, in: $V J a 11$ (4): 84-89.

CAMPBell, GeORGe L. (1991): Compendium of the World's Languages, Vol. II. London etc.: Routledge.

Comrie, Bernard (1981): Languages of the Soviet Union. Cambridge: CUP.

DROSSARD, WERNER (1997): Polysynthesis and polysynthetic languages in comparative perspective, in: PALEK, B. (ed.) Proceedings of Linguistics and Phonetics 1996. Prague: Charles University Press. 251-264

Dryer, Matthew S. (1986): Primary Objects, Secondary Objects, and Antidative, in: Language 62: $808-845$.

Foley, William A. (1991): The Yimas Language of New Guinea. Stanford: Stanford University Press.

ForTescue, Michael (1984): West Greenlandic. London etc.: Croom Helm.

- (1994): Morphology, Polysynthetic, in: AsHER, R. E. (ed.), The Encyclopedia of Language and Linguistics, Vol. 5. Oxford etc.: Pergamon Press. 2600-2602.

GerdTs, Donna B. (1996): Incorporation, in: Zwicky, Arnold M. / Spencer Andrew J. (eds.), Handbook of Morphology. Oxford: Blackwell. 84-100

HATTORI, TAKeShi (1962): Versuch einer Phonologie des Südostgiljakischen II - Alternation, in: Journal of Hokkaido Gakugei University, Section I-A, Vol. 13 (2): 29-96.

- (1988): Giriyâkugo, in: Gengogaku Daijiten, Vol. I. Tokyo: Kenkyûsha. 1408-1414.

JAKOBSON, Roman (1971): Notes on Gilyak. Texte guilyak, in: Selected Writings II. The Hague: Mouton. $72-102$.

KöNIG, EKKEHARD (1991): The meaning of focus particles. London etc.: Routledge. 
Krejnovı̌, E. A. (1934): Nivxskij (giljackij) jazyk, in: AL'Kor, JA. P. (ed.), Jazyki i pis'mennost' narodov Severa III. Leningrad: Institut Narodov Severa (= Trudy po Lingvistike, Vol. 3). 181-222.

-(1937): Fonetika nivxskogo (giljackogo) jazyka. Moscow-Leningrad: Institut Narodov Severa (= Trudy po Lingvistike, Vol. 5).

- (1958): Ob inkorporirovanii v nixvskom jazyke, in: VJa 7 (6): 21-33.

- (1960): Vyraženie prostranstvennoj orientacii v nivxskom jazyke ( $\mathrm{k}$ istorii orientacii v prostranstve), in: Voprosy Jazykoznanija 9 (1): 78-89.

- (1966): Ob inkorporirovanii i primykanii v nixvskom jazyke, in: VJa 15 (3): 33-51.

- (1986): Ob imenax prostranstvennoj orientacii v nixvskom jazyke, in: Paleoaziatskie jazyki: sbornik naučnyx trudov. Leningrad: Nauka. 157-167.

Mattissen, Johanna / Drossard, Werner (1998): Lexical and syntactic categories in Nivkh (Gilyak). Theorie des Lexikons, Arbeiten des Sonderforschungsbereichs 282 Nr. 85. Düsseldorf: HeinrichHeine-Universität.

Mithun, Marianne (1984): The evolution of noun incorporation, in: Language 60: 847-893.

- (1988): System-defining Structural Properties in Polysynthetic Languages, in: ZPSK 41 (4): 442-452.

Nedjalkov, V. P. / Otaina, G. A. (1988): Resultative and Continuative in Nivkh, in: Nedjalkov, V. P. / Comrie, B., Typology of Resultative Constructions. Amsterdam: Benjamins. 135-151.

Nespor, Marina / Vogel, Irene (1986): Prosodic Phonology. Dordrecht: Foris.

Nichols, JohanNa (1986): Head-Marking and Dependent-Marking Grammar, in: Language 62: 56-119.

OtaInA, G. A. (1978): Kačestvennye glagoly v nivxskom jazyke. Moscow: Nauka.

PANFILov, V.Z. (1954): K voprosu ob inkorporirovanii. Na materialax nivxskogo (giljackogo) jazyka, in: VJa $3(6): 6-27$

- (1958): Složnye suščestvitel'nye v nivxskom jazyke i ix otličie ot slovosočetanij (k probleme slova), in: VJa 7 (1): 105-111.

- (1960): Problema slova i “inkorporirovanie" v nivxskom jazyke, in: VJa 9 (6): 50-58

- (1962, 1965): Grammatika nivxskogo jazyka. 2 Vols. Moscow-Leningrad: Nauka.

- (1968): Nivxskij jazyk, in: Jazyki Narodov SSSR, Vol. 5 (Mongol'skie, Tunguso-Man'šžurskie i Paleoaziatskie jazyki). Leningrad: Nauka. 408-434.

Rosen, Sara Thomas (1989): Two Types of Noun Incorporation: A Lexical Analysis, in: Language 65: 294-317.

Savel'eva, V. N. / TAKSAmi, C. M. (1970): Nivxsko-Russkij Slovar'. Moscow: Sovetskaja Enciklopedija.

Shibatani, MASAYOShi (1990): The Languages of Japan. Chicago: CUP.

SKorik, PJotr (1961): Grammatika čukotskogo jazyka. Vol. I. Moscow: Izdatel'stvo Akademii Nauk.

SPENCER, ANDREW (1995): Incorporation in Chukchi, in: Language 71: 439-489.

- (1996): Phonology. Oxford: Blackwell.

TAKSAMI, C. M. / PolET'Eva, C. F. (1992): Raduga. Kniga dlja dopolnitel'nogo čtenija v 1-2 klassax Nivxskix škol. St. Peterburg: Prosvě̌čenie.

Watanabe, Michiko (1983): Giriyâkugo, in: Gengo 12 (11): 62-69.

- (1992): Giriyâkugo tadôshibun no tokuchô, in: MiYAOKA, Osahito (ed.), Kita no Gengo: Ruikei to Rekishi. Tokyo: Sanseido. 179-190.

Johanna Matrissen

Seminar für Allgemeine Sprachwissenschaft

Universität Zürich

Plattenstr. 54

CH - 8032 Zürich (Switzerland)

mattissn@spw.unizh.ch 